\title{
A Systematic Framework of Experiential Learning: Challenging Educators to Make College more than an Aggregation of Credits
}

\author{
Alana Dillette, Lori Sipe \\ L. Robert Payne School of Hospitality and Tourism Management, San Diego, CA, USA \\ Email: adillette@sdsu.edu, lsipe@sdsu.edu
}

How to cite this paper: Dillette, A., \& Sipe, L. (2018). A Systematic Framework of Experiential Learning: Challenging Educators to Make College more than an Aggregation of Credits. Creative Education, 9, 1426-1443.

https://doi.org/10.4236/ce.2018.99106

Received: June 13, 2018

Accepted: July 23, 2018

Published: July 26, 2018

Copyright ( $\odot 2018$ by authors and Scientific Research Publishing Inc. This work is licensed under the Creative Commons Attribution International License (CC BY 4.0).

http://creativecommons.org/licenses/by/4.0/

\begin{abstract}
This article examines experiential learning within the context of leader development in a hospitality and tourism management program. First, we present findings about high impact experiences from student blogs $(n=60)$ and discuss key themes within the context of Kolb's four phases of experiential learning. This is followed by a discussion about how these findings influence the systematic redesign of our core leadership curriculum. Findings suggest strong consideration be given to providing contexts for authentic practice, encouraging exploration and personalization, mentoring both ways, and the value of integrated and well-timed facilitation. A four-year framework is presented detailing specific high impact experiences and outcomes aligned with a progression of leader development for undergraduates.
\end{abstract}

\section{Keywords}

Experiential Learning, Leadership Development, Mentoring, Personalization, Framework

\section{Introduction}

Education in the field of hospitality and tourism management (HTM) has long been known for its focus on managing service quality (Testa \& Sipe, 2012). However, one of the major shifts facing business organizations involves the growing importance of experiential consumption (Kindstrom \& Kowalkowsi, 2014). Toffler, in his book Future Shock (1970), once envisioned a marketplace that would deal with a new level of human needs. He predicted that under more affluent conditions, businesses would be geared toward offerings that improved psychic gratification and quality of life. He called this strange new sector "expe- 
rience industries". More recent developments by Pine and Gilmore (2011) extended this concept by distinguishing the differences between the service economy and the experience economy. Their argument is based on the premise that contemporary businesses are moving in the direction of offering memorable, authentic and transformational experiences as opposed to merely satisfying customer needs (Pine \& Gilmore, 2014). In response to this shift in perspective, we feel that it is important that management educators attempt to mirror these changes and incorporate them into learning spaces dedicated to developing leaders in the emerging experience economy.

Within the context of the experience economy, a recent study of recruiters identified three themes related to management program graduates specifically focused on hospitality and tourism-deficiency in soft skills, inadequate work experience, and overreliance on academic accolades (Kitterlin-Lynch, Williams, \& Zheng, 2015). As a result, the authors recommended three avenues to better prepare graduates for management careers in the hospitality and tourism industry-curriculum development, experiential learning outside the classroom, and industry engagement (Kitterlin-Lynch et al., 2015). These recommendations are consistent with a broader study that posited college graduates are 2.4 times more engaged at work if they: 1) have had an internship that allowed them to apply classroom learning; 2) were active in co-curricular activities, and 3) worked on a project that lasted an entire semester or longer (Lives, 2014). However, only 6\% of college graduates reported having all three of those learning experiences.

Similarly, the idea of developing leaders through experiential learning has been steadily gaining popularity in both the workplace and educational spaces (Nikolova \& Andersen, 2017; Hezlett, 2016). In the workplace, experience driven development involves managers taking on projects and roles that enhance their leadership capabilities as opposed to relying solely on leadership training sessions. For example, the phrase "70-20-10" describes how much emphasis should be placed on development activities on the job versus relationship building versus formal training (McCauley, DeRue, Yost, \& Taylor, 2014). Three evidence-based practices that are touted by human resource development professionals include expatriate assignments, job rotation, and action research (Hezlett, 2016). Outcomes involve individual development of knowledge, skills, and competencies relevant to performing the managerial role as well as soft skill enhancements like the development of social capital that enhances the collective leadership capacities of the firm (Day \& Dragoni, 2015). In educational spaces, experiential learning is based on the concept of self-efficacy (Bandura, 1989). Essentially, within an educational context, students are more likely to believe they can complete a task successfully once they have had personal experiences within their specific field of study.

Unfortunately, in higher education institutions, one of the most traditional methods of teaching is the lecture approach. In contrast, the increasing attention and interest in high impact educational experiences is fueled by the belief that 
college is something more than the aggregation of credits (Kuh, O'Donnell, \& Reed, 2013). This article examines experiential learning within the context of leader development in a hospitality and tourism management program. Through purposeful curriculum design and progressive pedagogy, high impact experiences can enrich student learning and work to narrow the achievement gap across diverse student populations (Schneider, 2015). Therefore, the salient research questions for us were:

1) In what ways, if any, are our students currently engaging in high impact experiential learning?

2) How do we systematically integrate high impact experiential learning into our core curriculum design (Freshman-Senior) to better prepare our students to lead in the experience economy?

We took an educational design approach to the research initiative with the dual aim of generating research-based solutions in educational practice and advancing our knowledge about the characteristics of these interventions (Edmonds \& Kennedy, 2013). In the first section, we draw from leadership development and experiential learning theories to outline propositions underlying the research in context. Next, we summarize the findings from 60 student blogs and present them within the context of Kolb's experiential learning cycle. This is followed by a discussion about how these findings influenced the redesign of our core curriculum. A four-year grid is presented detailing specific experiential learning activities aligned with a progression of leader development for undergraduate management students. The final section discusses implications for future research and makes recommendations for management educators.

\section{Theoretical Foundations}

\subsection{Leadership Development Theory}

Leadership development has typically been considered within the realm of human resource management. The focus is on developing managers to be effective in their roles as leaders (DeRue \& Myers, 2011). This approach tends to endorse an individualistic and hierarchical conception of leadership. Contemporary views reflect an emerging shift toward thinking of leadership as a shared process that anyone can participate in, regardless of formal position. Day (2000) distinguished the concepts of leader development and leadership development. Leader development focuses on individual development such as the knowledge, skills, and abilities required by formal leadership positions (Day, 2000). Leadership development emphasizes using interpersonal competence and relationship building with others in an organization to develop social capital (Day, 2000). This is consistent with leadership research about identity that suggests leader self-development progresses from the individual level to the relational level to the collective level (Lord \& Hall, 2005). We agree with the notion that supporting individual leader development will not only increase the individual's competencies, but over time will result in enhancing the organization's leadership ca- 
pacity as a whole (Reichard \& Johnson, 2011).

Proposition: Leadership development involves learning about and practicing leadership at the individual, relational, and collective levels.

Boyatzis (2006) described individual development as a sequence of discoveries he called intentional change theory. First, the individual creates a personal vision of the ideal self and compares that to the real self to create an assessment of one's strengths and weaknesses. A develop plan is created that involves a series of experimentation and practice with new behaviors intended to bring one closer to the ideal self. Some scholars stress the importance of leader development as a self-directed process. In leader self-development, learning is centered on the leader, who initiates and becomes an active participant in the learning process, to include which needs are most important and the type of activities that, over time, will bring them closer to their goals (Petrie, 2014). Leaders practice their "craft" in a variety of social and organizational settings, and recent theories have stressed the importance of looking at leadership as embedded in context (Kellerman, 2012). Similarly, an emerging stream of leadership development research reflects an argument that a high proportion of leadership development should be the result of learning from experience. There is growing empirical evidence that key development activities like action learning and stretch assignments promote workplace leadership development (Hezlett, 2016).

Proposition: Leadership development is facilitated through context-embedded experiential learning activities.

Many contemporary academic and practitioner models point to the relevance of feedback to leadership development. Feedback seeking behavior helps people develop a more accurate view of their strengths and weaknesses, which ultimately influences subsequent behavior and decision-making (Taylor \& Hood, 2011). Ongoing feedback is helpful as leaders apply or transfer knowledge, behaviors, and skills in increasingly challenging developmental experiences (Hezlett, 2016). Likewise, reflecting on experiences has been linked to gains in self-efficacy, changes in interpersonal behavior, and improved future performance (DeRue \& Myers, 2014).

Proposition: Experience driven leadership development will be enhanced by ongoing opportunities for feedback and reflection.

\subsection{Experiential Learning Theory}

Experiential learning theory is defined as "the process whereby knowledge is created through the transformation of experience; knowledge results from the combination of grasping and transforming experience" (Kolb, 1984: p. 41). Essentially, experiential learning theory is a holistic idea that merges concepts of concrete experience as the best teacher and the acquisition of knowledge through critical thinking and reflection. The theory was called "experientiap" learning to stress the importance of the experience as central to the learning process, as opposed to other types of learning theories. Original tenants of the 
theory were built on six main propositions shared by multiple scholars as descripted by Kolb and Kolb (2005):

1) Learning is a process. The focus of learning should be that it is continuous, with touch points for feedback and engagement with students along the way.

2) All learning is relearning. Nothing is ever learned in its entirety the first time around. Deep learning will come from the process of critically assessing ones current stance on an idea or topic and refining this stance to be incorporated with the current environment.

3) Learning requires the resolution of conflicts. Learning does not occur in one sphere where a group of thinkers similar to ourselves may surround us. Learning requires sorting through conflict, disagreement and differences with others.

4) Learning is a holistic and continuous process of adaption. Learning is not only "knowledge based", but requires the integration of the whole person utilizing action, reflection, thinking and feeling.

5) Learning is the result of transactions between the person and their environment. "Learning occurs through equilibration of the dialectic processes of assimilating new experiences into existing concepts and accommodating existing concepts to new experience" (p. 194).

6) Learning is the process of creating knowledge. Knowledge is created within the context of the learner's experience. It is facilitation by a teacher providing opportunities for the creation of knowledge rather than simply the transmission of knowledge from the teacher to the learner.

Clearly there is significant crossover between key propositions embedded in Kolb's theory of experiential learning and leader development theory that can inform curriculum design in the experience economy. First, as indicated by the propositions outlined above, context matters (Kellerman, 2012). Second, development and learning is highly personalized (Boyatzis, 2006). Third, a student's leader development involves generative learning that occurs over time (Kolb \& Kolb, 2005). And finally, educators and other influencers can facilitate (and/or hinder) learning and development (Kolb \& Kolb, 2005).

\subsection{Kolb's Four Phase Learning Cycle}

Kolb (1984) synthesized experiential learning theory within a four phase learning cycle including concrete experiences, reflective observation, abstract conceptualization and active experimentation. Concrete experience refers to a tangible experience you can physically take part in actively or passively. This concrete experience could be a new experience encountered, or an old experience re-encountered. Reflective observation occurs after you have had the concrete experience, special attention should be paid to what you experienced and what you learned. Abstract conceptualization on the other hand refers to thinking about the concrete experience in hopes of gaining understanding. Abstract conceptualization can often lead to a new idea or modification of an old idea. Active experimentation occurs when the student or person applies what they have 
learned in their surrounding environment outside the confines of a classroom.

Kolb and Kolb (2005) argue that experiential learning is "a process of constructing knowledge that involves a creative tension among the four learning modes that is responsive to contextual demands. This process is portrayed as an idealized learning cycle or spiral where the learner 'touches all the bases'-experiencing, reflecting, thinking and acting-in a recursive process that is responsive to the learning situation and what is being learned" (p. 194). Effective learning within Kolb's model occurs when a person progresses through all four stages, and, as a result, uses the information gained to learn in future situations.

Kolb's theory has been utilized in multiple disciplines, but is fairly limited within the hospitality and tourism field. However, studies that have been done include those who utilized Kolb's theory to understand different experiential learning approaches for hospitality and tourism management education (Ruhanen, 2006) the use of real world case studies in the classroom (Green \& Erdem, 2016), the effect of internships on classroom learning (Stansbie, Nash, \& Chang, 2016) and the experiences of students who engaged in a service learning project (Lin, Kim, Qiu, \& Ren, 2017). Amongst these studies, we discovered findings that indicated experiential learning activities such as internships and real world case studies do in fact have a positive effect on the learning outcomes of students. More specifically, Stansbie et al. (2016) reported on the learning students experienced before, during and after their internships and how these experiences were all integrated. While the findings of these studies are pertinent and did expand the knowledge base in our field, we felt that the literature was still lacking; specifically in the area of understanding when students should be experiencing learning in each of Kolb's suggested phases. To fill this gap, we set out to not only understand how our students are engaging with high impact learning practices, but also when these experiences are occurring, with the hopes of using these findings to inform curriculum redesign and to enhance generative, personalized learning and leader development for our students.

\section{Methods and Findings-Research Question \#1}

Educational design research occurs in iterative cycles. Analysis, design, evaluation, and revision activities are iterated until an appropriate balance between the ideals and realization has been achieved (Anderson \& Shattuck, 2010). The first phase of our research was aimed at answering the question in what ways, if any, are our students currently engaging in high impact experiential learning?

The sample is from an undergraduate hospitality management program in California. Students in the program are $65 \%$ female, most are working in the hospitality industry, and the program requires a high GPA (B average or better) to be accepted. Currently, students in our program are required to develop a professional blog in one of their capstone senior leadership courses. The blog is designed to engage students in a reflective process about their learning and development through a series of prompts around topics like leadership develop- 
ment, industry connections and promising pitfalls. Prior to this study, we had never holistically reviewed these blogs (apart from grading purposes) to gather insight into what our students were finding to be the most impactful experiences of their undergraduate career. Therefore, in order to gain a better understanding of this work, we set out to analyze a grouping of these blogs using a stepwise structural thematic coding method (Saldaña, 2015). To begin, we randomly selected 15 blogs from four different sections of the same senior leadership course, for a total of 60 blogs included for analysis. Prior to moving forward, we separately read each blog to familiarize ourselves with the data and to determine if data saturation had been reached. Based on this familiarization process, we determined that there were enough overlapping themes and experiences amongst the selected blogs to determine saturation within the data. We agreed there was rich qualitative data that revealed the current state of our students' perspectives on their leadership development. In this initial phase, free codes were developed based solely on the content of the data, without yet attaching Kolb's experiential learning theory. As the next step in the process, we created a thematic codebook where passages from the blogs were lifted from their original text and assigned to codes identified in the initial familiarization process. We also reviewed each code for its distinctiveness as compared to other codes, with the goal of decreasing the amount of codes that were overlapping with each other. For example, original codes labeled 'growth' and 'growing' were merged into one code. This allowed us to begin to visually see which themes were particularly powerful and reoccurring across different student blogs, in addition to identifying passages that captured the essence of a particular theme (Creswell, 2011). The final list included 30 codes linked to 8 overarching themes.

Once we solidified this list of codes along with the overarching themes, we then began the process of associating codes with the four overarching themes of Kolb's experiential learning theory. This was an iterative and integrative process between the researchers, where we talked back and forth about the specific meaning of each code and how it related to Kolb's theory (Creswell, 2011). Student reflections gathered for this research revealed eight major themes: 1) authentic networking; 2) involvement outside the classroom; 3) study abroad experiences; 4) student/professor relationships; 5) challenges outside comfort zones; 6) the power of mentorship; 7) real world opportunities through jobs and internships; and 8) leadership with meaning. Based on in depth analysis of each theme, we grouped these themes into four larger overarching categories aligning them with Kolb's experiential learning theory. Each theme and overarching category is represented in the synoptic chart below (Figure 1).

\subsection{Concrete Experiences}

In relationship to concrete experiences, we found that students most closely related "authentic networking", "involvement outside the classroom" and "study abroad" with this phase of Kolb's Experiential Learning Theory. Within each of 


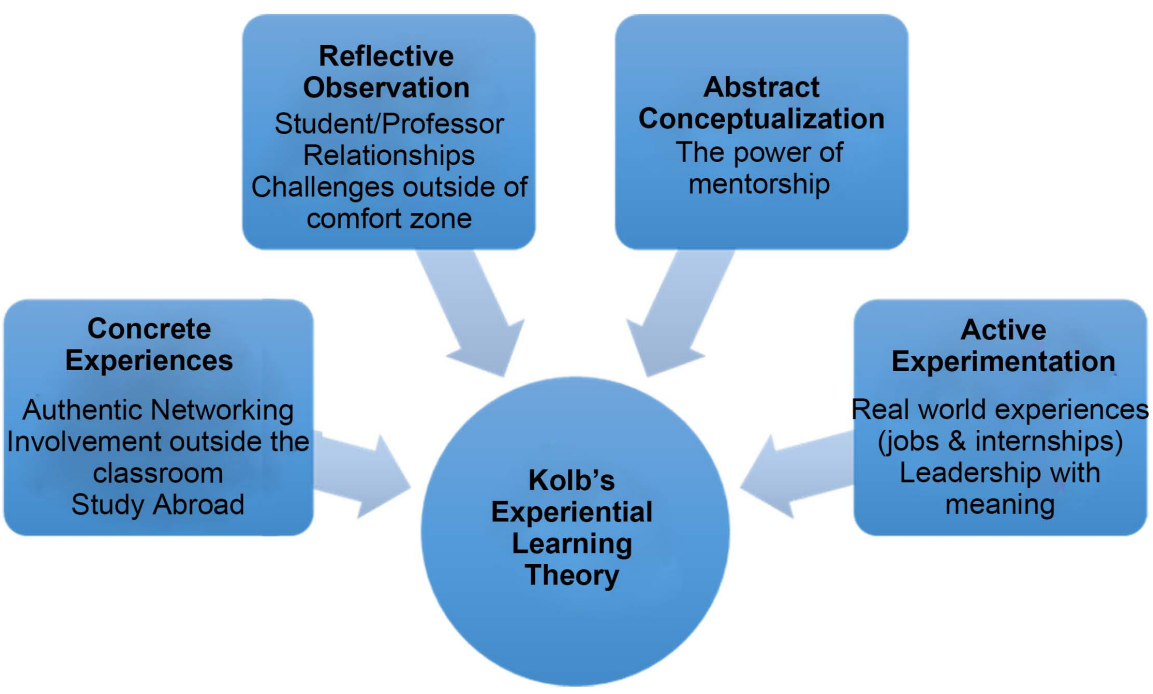

Figure 1. Synoptic chart. This figure illustrates overarching themes and their connection to Kolb's experiential learning theory.

these themes, our thematic analysis of the data revealed commonalities amongst students engaging in new experiences or situations that allowed them to re-interpret or re-imagine their previous knowledge base. For example, numerous students reflected on concrete experiences they had networking with industry professionals both inside the classroom, through guest speaker visits, and outside the classroom, through informational interviews and job shadows. It was clear to us that these opportunities felt tangible to students, and, for many, presented an unmatched opportunity to engage in real-life learning experiences. Two excerpts below share the reflections students had about an authentic networking opportunity that came full circle:

"During HTM 301, one of my industry professional graders, Michael* and I were walking out of the building chatting about Omni Hotels and he got me interested in the Omni company. Earlier this semester I applied for Omni's Management Training program, ironically he was the one interviewing me for the program and remembered who I was and how I worked with my team during the 301 projects."

"After my day of shadowing was over I sent the event manager a card thanking her for her time. We kept in touch and about 4 months later I reached out to her because I was looking for another job in the Hospitality industry. She got me in contact with the Front Office Manager and put in a good word. Currently I work at the Andaz San Diego."

When reading through these excerpts, and many others shared by other students, we felt the tangibility and authenticity of these students as they were realizing the real benefits of true "authentic networking". As evidenced by the quotes shared here, and many others within the blog data, providing opportunities for students to engage authentically with professionals made a huge difference to their learning experience as a college student. One student even delves 
into how attending a networking event changed their perspective on their own leadership identity and confidence:

"This the very first time I ever went to a networking event and I was terrified! My friends and I were pushed into it (of course) by school but honestly if they didn't make us go, I probably wouldn't have gone. At this first event I learned the importance of self-branding and putting yourself out there for the world to see. No one can hire you if they can't find you!"

Another theme that occurred consistently amongst students was the encouragement and opportunity to get involved in experiences outside the classroom, specifically, in opportunities provided through student organizations on campus. Two quotes below characterize the support students felt after becoming involved with student organizations, consequently, leading them both to very rewarding learning experiences outside the classroom:

"I was ready to leave college, because it wasn't for me. I really think, when I look back on it now, that finally getting involved in student organizations provided me with the confidence to stay in school. The support system I gained and the friends I made encouraged me to be the best I could be, and I am forever gratefup'.

"This organization put me way outside my comfort zone having not known anyone coming into college and challenged me to meet people who were interested in the same career as me. I was scared to start with this organization on campus, but am so glad that I stuck it out and it was one of the most rewarding experiences."

To round out concrete learning experiences, many students reflected on the once in a lifetime opportunity they got to study abroad internationally while in University. As we read through the excerpts related to this theme, the general consensus was that students left to study abroad nervous and afraid, and returned back to school changed forever. Phrases like "life-changing" and "perspective shifting" were used to describe the experiences students had while learning in another country. One student reflects on their trip to Spain as a concrete experience that changed their entire outlook on life:

"I was fortunate enough to study abroad in Barcelona, Spain during spring semester. This was probably one of the biggest steps outside my comfort zone I could have possibly taken. I had never been out of the country before, but I can honestly say that studying abroad changed me and my outlook on life in such a positive way."

Another student reflects similarly, but takes the further initiative to pass on their experiences to others in hope of inspiring another student to take a similar step outside of their comfort zone.

"I wanted to encourage more students to be a part of such a life changing event! So I organized with the International Student Center on campus at SDSU to present about my experience and give advice to prospective study abroad students." 
In this case, the student not only gained perspective from their experience, but took this experience as a stepping stone to help others who may have still been hesitant. This movement towards enacting change in others was probably one of the most significant things that emerged from students' reflections on their concrete learning experiences.

\subsection{Reflective Observation}

Reflective observation refers to the learning process that occurs after participating in a concrete experience. Of particular importance to this phase of learning is the comparison between theatrically understanding a concept and experiencing the concept in real time. We found themes related to this learning phase revolved around students being challenged and pushed by their professors, both in and outside the classroom. More specifically, the themes "student/professor relationships" and "challenge us, push us, we're better for it", were used to categorize learning experiences in the reflective observation category. When it came to students relationships with their professors, they often reflected on the fact that, though certain projects and assignments were stressful, they ultimately understood the meaning and importance behind them. Students reflect specifically on being thankful for having professors who care and who developed assignments that really challenged them, but better prepared them for the field:

"My professors have formed a bond with us that will never be broken and always be remembered. They have pushed us to learn and did not stop until we understood the topics that they presented to us. The long nights of studying and extensive group projects all had meaning behind them."

"The reason that I wanted to highlight this one small quiz is because of the impact it made on the rest of my schooling as well as work. These words are immersed in the industry so much, and are expected to be known right off the bat of any job. Dr. Smith* upped the stakes of making all of these words memorized together in a very short period of time. At the time, I hated her for it, now, I couldn't be more grateful for it, and owe her a huge thank you."

Students expanded on this concept more deeply and reflected on being grateful for an environment that challenged them to be the best version of themselves, to look closely in the mirror at who they are-strengths, weaknesses and everything in between. These two themes are closely interrelated and intertwined.

"With HTM I was able to be me and accomplish projects that I never thought I would do. HTM is for anyone who wants to be a leader, step out of the box and really get to know your true self, while being a full time student and working 30 hours a week. I will always live up to the "above and beyond" that all of the HTM professors say."

\subsection{Abstract Conceptualization}

Abstract conceptualization was the most difficult classification to "categorize", most likely due to the fact that this type of learning experience is highly intangi- 
ble, and birthed through reflection. Abstract conceptualization gives rise to a new idea, or modification of an existing abstract concept. After analyzing the data, we made the connection between this learning phase and one major theme- "the power of mentorship". Uniquely, in this case, mentorship refers to older students mentoring younger students as a part of a class assignment. In this way, students were able to first learn about different theories of leadership, network authentically with different leaders, and then practicing their leadership in the form of mentoring. Two students reflect on how this experience of mentoring helped them to understand the process of leading and learning in a new way:

"I realized that it is a privilege to have the opportunity to mentor someone. It is extremely rewarding to have an individual who cares about your experience and opinions."

During my time as a mentor for a student in 301, I was nervous, scared-to be honest, I felt like I was going to be inadequate. But, I made a commitment to my mentee and stuck to this. By following the steps and simply being there for my mentee, I was able to build a relationship with her and help her succeed in her classes. This meant so much to me and has helped me to understand some of the leadership theories we have learned in class. I now believe that, by the time I graduate, I will be ready to actually lead and not just manage."

This form of abstract conceptualization shed light on student beginning to take their first steps into leadership roles and understanding who they are as leaders. College level learning and experiences should be about getting students to this point of being able to envision themselves as leaders in the workplace.

\subsection{Active Experimentation}

As the fourth and final phase of Kolb's theory, active experimentation combines everything students have learned and been able to reflect on and allows them to experiment within the world around them. Themes reflected on by students included "real world experiences (jobs \& internships) and projects that enabled them to "lead with meaning". One of the cornerstones of hospitality and tourism programs is often a requirement that students gain practical work experience prior to graduating. Providing students with this opportunity to actively experiment not only prepared them for leadership positions upon graduation, but, it also allows them to figure out what they like and don't like in the workplace. One student reflects on an experience that helped to illuminate which emphasis area she was truly passionate about:

“After volunteering for several events, I realized that I really didn't like it, and sadly, wasn't even good at it. Half way through the semester I switched over to restaurant management and my life started making sense again. I don't regret starting as an event student though, because it has always been something I have been curious about! I'm just glad I realized it wasn't my thing before it was too late. What can I say, once a foodie always a foodie.

Another student reflects on being able to not only gain work experience out- 
side the classroom, but, also, to witness, in real time, the theories learned in the classroom being executed in the field.

"Everyday I find myself taking the things I have learned in the classroom out into my everyday life. I never thought I would feel as prepared as I do to face the big, bad world."

Seeing students make these kinds of connections between their concrete experiences, all the way through active experimentation is really the goal of a university degree, no matter the field.

Finally, one of the major, and most meaningful themes that emerged from the data, was student reflections actively experimenting with leadership. These learning experiences were derived from student projects designed to challenge students to implement what they have learned into a project that has tangible impact. One of the projects many students reflected on was their senior capstone project, which addresses a real problem in the industry. Students are required to work in large groups, taking on different positions, with the final product being a presentation to their stakeholders. One student, reflects, mid project, on what she has learned thus far in the process:

"The big ' 15 group project I am working on right now is to pitch a restaurant concept to a man that is actually opening up a restaurant in September. For the past 3 months, I have had first-hand experience realizing what it's like to work on a project with 15 other students. It's been challenging all coming to ideas that $w$ all agree with, as well as delegating tasks. Right now, I kind of want to ring my hair out.... but I know after next week I will be really grateful for what this project has taught me."

Another student reflects on how they have learned to lead with meaning in the workplace based on their experiences being challenged as a student:

"So how may you ask is it that I got promoted and they didn't? The number one reason is because I came to work with a different mindset everyday. I didn't come ready to "be the best server" or to sell the most in revenue. I came in with a mindset of wanting to help my team out everyday, and to make sure not just my tables were happy, but that everyone's tables were happy. After a talk with my managers they told me one thing that will always stick with me: "The goal is not to be the best at your job when trying to get promoted. It's about being that person that everybody looks forward to working with, and putting other's interests before your own." After this recent experience, I am proud to say that I truly have a good grasp on what my leadership philosophy is. I believe that I am in the process of becoming a transformational leader who doesn't just direct people below me, but rather inspires them to work better to change the world."

\section{Methods and Findings-Research Question \#2}

Educational design research is typically based on a theoretical framework, but the research aims at designing an intervention in a real world setting. As suggested by design research authors, we conducted a reflective review of our initial 
findings with other educators responsible for curriculum delivery in our program's leadership core (Anderson \& Shattuck, 2010). Our discussion was guided by our second research question how do we systematically integrate high impact experiential learning into our core curriculum design (Freshman-Senior) to better prepare our students to lead in the experience economy? Driven by the findings from research question \#1, we collectively created a grid of high impact experiences that integrate Kolb's learning theory and leader development theory.

As depicted in Table 1, the first year is focused on the development of a baseline leadership identity. Students create an initial personalized electronic portfolio and professional passions career map that will be used throughout their stacked leadership coursework. They are required to engage with on-campus student organizations as well as industry professionals. Identifying oneself as a leader is considered a critical first step toward continual development as a leader (Lord \& Hall, 2005). During the second year, students observe and reflect on a variety of leadership styles. Through volunteering, job shadows, and part-time work, students link classroom learning about leadership with active experimentation of leader-follower interactions. Educator facilitation is emphasized as students practice and reflect in a variety of organizational contexts and upload key artifacts to their electronic portfolio.

During the student's third year, the focus is on active experimentation and abstract conceptualization with an emphasis on the leader/follow dyad. Students participate in a rotational internship where they reflect on their professional passions and update their career mind map. They are required to study abroad as well as complete a personalized leader development project. Their leadership coursework focuses on the leader/follower relationship, and they practice the coaching cycle while formally mentoring a freshman or sophomore student in the program. We intend this year to enhance student leader development through interactions that trigger abstract conceptualizations around the importance of relational influences (Northouse, 2016).

Students take on more challenging real world projects with client deliverables in their fourth year. They complete a capstone course project in a team of $15-18$ students, providing opportunity to practice leadership of an organization. They also begin to take even more ownership of their personal leader development journey. Their second internship requires them to design and execute a workplace improvement project aligned with their career goal. They finalize their electronic portfolio during their senior year, and articulate their personalized vision of leading with meaning.

In this study, we integrated data from student blogs with leadership development and experiential learning propositions to design high impact experiences for undergraduate students. The systematic framework presented in Table 1 was designed as a context-specific intervention, however, it is a useful tool for educators challenged with developing future leaders in the contemporary marketplace. The findings support existing theoretical constructs from previous research, in 
Table 1. Integrated systematic framework for experiential learning. This table summarizes and categorizes different high impact learning experiences based on year.

\begin{tabular}{|c|c|c|c|}
\hline \multicolumn{4}{|c|}{ Integrated Systematic Framework for Experiential Learning } \\
\hline Activity & Description & Kolb's Category & Connected Themes \\
\hline \multicolumn{4}{|c|}{ First Year-Development of baseline leadership identity through context \& personalization } \\
\hline $\begin{array}{l}\text { Industry guest } \\
\text { speaker visits }\end{array}$ & $\begin{array}{l}\text { Students will engage with professional industry guest speakers who visit } \\
\text { their first introductory class in the program. Guest speakers will share } \\
\text { information about their career journeys and the realities of their jobs in } \\
\text { the industry in a workshop format in the classroom. }\end{array}$ & Concrete Experiences & Authentic Networking \\
\hline $\begin{array}{l}\text { Student } \\
\text { organization } \\
\text { engagement }\end{array}$ & $\begin{array}{l}\text { Students will engage with a student organization event on campus. At } \\
\text { these events, students will have a chance to get involved and connect with } \\
\text { other students and industry professionals in the field. }\end{array}$ & Concrete Experiences & $\begin{array}{l}\text { Involvement outside the } \\
\text { classroom }\end{array}$ \\
\hline $\begin{array}{l}\text { Develop baseline } \\
\text { professional } \\
\text { e-portfolio }\end{array}$ & $\begin{array}{l}\text { Based on student experiences with professional guest speakers and other } \\
\text { class material from their introductory class, they will create their } \\
\text { professional e-portfolio to include reflections on the class, their career } \\
\text { path and baseline leadership identity. }\end{array}$ & $\begin{array}{l}\text { Reflective } \\
\text { Observation }\end{array}$ & $\begin{array}{l}\text { Student/Professor } \\
\text { Relationships }\end{array}$ \\
\hline $\begin{array}{l}\text { Baseline } \\
\text { Professional } \\
\text { Mind map }\end{array}$ & $\begin{array}{l}\text { Students will begin a professional mind map to represent their individual } \\
\text { career goals and strategies to achieve these goals moving forward. This } \\
\text { analysis will serve as a reflective look at their strengths and weaknesses and } \\
\text { as a benchmark for moving forward with their education and careers in } \\
\text { the field. Work on this map will continue each year while the student is in } \\
\text { college. }\end{array}$ & $\begin{array}{l}\text { Reflective } \\
\text { Observation }\end{array}$ & Challenge us \\
\hline \multicolumn{4}{|c|}{ Second Year-Observing and reflecting on different leadership styles through educator facilitation } \\
\hline $\begin{array}{l}\text { Solve real world case } \\
\text { studies }\end{array}$ & $\begin{array}{l}\text { Students will learn and practice with tools related to gathering data, } \\
\text { creating spreadsheets and graphics with that data, summarizing data. } \\
\text { Students will be tested on these skills in the forms of in class activities, } \\
\text { exams and presentations. }\end{array}$ & $\begin{array}{l}\text { Reflective } \\
\text { Observation }\end{array}$ & $\begin{array}{l}\text { Student/Professor Rela- } \\
\text { tionships }\end{array}$ \\
\hline $\begin{array}{l}\text { Industry } \\
\text { Informational } \\
\text { Interviews }\end{array}$ & $\begin{array}{l}\text { Students will contact and conduct face-to-face interviews with industry } \\
\text { professionals working in the career they are interested in. }\end{array}$ & Concrete Experiences & Authentic Networking \\
\hline $\begin{array}{l}\text { Exploring careers } \\
\text { reflection paper }\end{array}$ & $\begin{array}{l}\text { Students will combine their gathered data from the industry interviews } \\
\text { with secondary research and write a final research paper on the project. }\end{array}$ & $\begin{array}{l}\text { Reflective } \\
\text { Observation }\end{array}$ & $\begin{array}{l}\text { Student/Professor } \\
\text { Relationships }\end{array}$ \\
\hline $\begin{array}{l}\text { Experimental work } \\
\text { experiences }\end{array}$ & $\begin{array}{l}\text { Students will be required to gain work experience in the field. As students } \\
\text { volunteer and gain work experience in their part time jobs, they will both } \\
\text { practice leadership in a real world setting and observe the leadership of } \\
\text { others. }\end{array}$ & $\begin{array}{l}\text { Active } \\
\text { Experimentation }\end{array}$ & $\begin{array}{l}\text { Work } \\
\text { Experience/Internships }\end{array}$ \\
\hline \multicolumn{4}{|c|}{ Third Year-Practicing leadership in the context of coaching and mentoring } \\
\hline $\begin{array}{c}\text { Professional rota- } \\
\text { tional internship }\end{array}$ & $\begin{array}{l}\text { Students will complete an internship with an organization in the } \\
\text { hospitality and tourism field that allows them to rotate through different } \\
\text { departments (i.e. rooms, food and beverage, housekeeping etc). }\end{array}$ & $\begin{array}{l}\text { Active } \\
\text { Experimentation }\end{array}$ & $\begin{array}{l}\text { Work } \\
\text { Experience/Internships }\end{array}$ \\
\hline Study abroad & $\begin{array}{l}\text { Students will complete a study abroad trip in another country for at least } \\
\text { two weeks or more. }\end{array}$ & Concrete Experiences & Study abroad \\
\hline Mentorship Activity & $\begin{array}{l}\text { Students will participate in a mentorship activity where they act as the } \\
\text { mentor to a younger student in the program. }\end{array}$ & $\begin{array}{l}\text { Abstract } \\
\text { conceptualization }\end{array}$ & Mentorship both ways \\
\hline $\begin{array}{l}\text { Leadership } \\
\text { Development } \\
\text { Project }\end{array}$ & $\begin{array}{l}\text { Students will develop and complete a personalized leadership development } \\
\text { project where they actively work through leading a team or project and } \\
\text { link their experiences back to leadership theory. }\end{array}$ & $\begin{array}{l}\text { Active } \\
\text { Experimentation }\end{array}$ & Leadership with meaning \\
\hline
\end{tabular}




\section{Continued}

\begin{tabular}{|c|c|c|c|}
\hline \multicolumn{4}{|c|}{ Fourth Year-Solidifying leadership style and understanding leadership as a process } \\
\hline $\begin{array}{l}\text { Professional } \\
\text { Internship } 2\end{array}$ & $\begin{array}{l}\text { Students will complete an internship in line with their desired job post } \\
\text { graduation. }\end{array}$ & $\begin{array}{l}\text { Active } \\
\text { Experimentation }\end{array}$ & $\begin{array}{l}\text { Work } \\
\text { Experience/Internships }\end{array}$ \\
\hline $\begin{array}{l}\text { Senior capstone } \\
\text { project }\end{array}$ & $\begin{array}{l}\text { Students will work in a group to combine the skills and knowledge they } \\
\text { have practiced over their degree into one final capstone project that works } \\
\text { to solve a real world case in the industry. }\end{array}$ & $\begin{array}{l}\text { Active } \\
\text { Experimentation }\end{array}$ & Leadership with meaning \\
\hline $\begin{array}{l}\text { Client change } \\
\text { presentation }\end{array}$ & $\begin{array}{l}\text { Students will put together a professional presentation that they present to } \\
\text { industry professionals. }\end{array}$ & $\begin{array}{l}\text { Active } \\
\text { Experimentation }\end{array}$ & Leadership with meaning \\
\hline $\begin{array}{l}\text { Complete final } \\
\text { e-portfolio and blog }\end{array}$ & $\begin{array}{l}\text { Students will complete their final e-portfolio which spanned over all four } \\
\text { years, including a reflective blog on their learning experiences as a college } \\
\text { students. }\end{array}$ & $\begin{array}{c}\text { Reflective } \\
\text { Observation }\end{array}$ & $\begin{array}{l}\text { Student/Professor } \\
\text { Relationships, Leadership } \\
\text { with meaning }\end{array}$ \\
\hline
\end{tabular}

addition to revealing some new areas for consideration in the development of high impact learning activities.

First, similar to those of Kolb and Kolb (2005), Hezlett (2016) and Kellerman (2012), our findings indicate that activities embedded in context specific situations are important and necessary for student development in the field and as leaders. In our research it became evident that students thrived in situations where they were able to see theoretical frameworks in action. Whether that be through listening to a guest speaker in their first year, observing a leader in the workplace during their second year, or actively going out into the field themselves and learning individually within their own organizational contexts. Engagement with these context specific environments is important for students to not only learn, but to also be able to apply their learning in different real-world situations. You will notice that opportunities for context specific activities are embedded throughout our four-year framework, which brings us to our second finding embedded in existing theory. Learning must be generative. As noted earlier in the paper by Kolb and Kolb (2005), learning is a process that occurs cyclically and at different levels, individually, relationally and collectively (Lord \& Hall, 2005). Kolb and Kolb (2005) also argue that all learning is re-learning and occurs throughout a generative process. Our student reflections indicated this to be true through experiences of learning coming full circle, reflecting on something they learned in a previous class and were able to connect later to another experience.

Expanding the idea of generative learning further, our research found that learning through exploration is just as important, if not more important, that the transmission of knowledge. Student reflections revealed that the ability they were given to explore their own paths truly led to their own growth, self-development and empowerment (Petrie, 2014). This finding expands the original idea that learning is cyclical, into the explorative realm of learning in management education. We also found that it was very important for our students to feel that their learning was personalized. Similar to the proposition posed by Reichard and Johnson (2011), our findings indicated that while yes, students learn collectively 
and in groups, it is important for students to also be able to explore their own passions and goals individually. Our findings also revealed the importance of authenticity in learning. Many times, especially in higher education, we feel confined to over teach idealistic theory and under teach authentic reality. Finding a balance between these two equally important facets of the learning process allows students to have more authentic high impact learning experiences.

Lastly, we confirmed that students value the facilitation that their professors provide, and this the relationships built between student and professor. This finding supports Kolb and Kolb's (2005) argument that learning as a process of creating knowledge through the facilitation of opportunities by educators, rather than the simple transmission of knowledge. As an extension of this finding, a specific area of importance that our findings revealed was that educator facilitation of opportunities for leadership and mentorship are important. Providing opportunities systematically integrated with coursework for students to actively practice both these skills was a strong point amongst student reflections. Further to this, and perhaps most notable to point out is the fact that this facilitation must not occur in silos, but rather as a team. Educators need to work together to facilitate a comprehensive experience for students in their program to graduate with a holistic and interconnected learning experience, rather than with a slew of choppy and disconnected coursework, which, unfortunately, sometimes occurs in higher education. Our proposed systematic framework is a prime example of this. When developing the framework, we were forced to ask ourselves questions such as "Where are we overlapping?", "How does each course and year connect to the next?", "What are we missing?", "How do we fill in the gaps?" These questions, amidst numerous iterative discussions, are what led to the systematic framework you see presented in this study.

It is also important to note that Kolb's theory, though we have included all four phases, they did not occur in isolation within each year of a student's college experience. We noticed, for example, that concrete experiences bled into reflective observation over numerous years. Experiences curated inside the classroom (i.e. group projects and reflective essays) are equally as important as those outside the class (i.e. internships and industry informational interviews). It is in tandem that these experiences hold their power, and the ability to empower lifelong learning in students. The proposed framework identifies different ways to systematically incorporate these types of learning experiences into any management education focused classroom.

The future of this type of work lies in measurement. Moving forward, it will be important to ask ourselves how we can measure the impact of these types of frameworks, how we can intervene into student learning experiences that are mid-stream and, most important, should we be attaching more weight to experiential learning that occurs outside the classroom? As educators, it is important to remember that teaching students how to critically think, link knowledge across ideas and eventually, create new knowledge and ideas does not come overnight. It is the process of repetition, and guided reflection that will allow 
students to eventually enter into this space. It is our hope that, through the proposed and thoughtfully designed high impact experiential learning framework, other management educators can feel empowered to provide the impactful education that all students deserve.

\section{References}

Anderson, T., \& Shattuck, J. (2010). Design-Based Research: A Decade of Progress in Educational Research? Educational Researcher, 41, 16-25. https://doi.org/10.3102/0013189X11428813

Bandura, A. (1989). Regulation of Cognitive Processes through Perceived Self-Efficacy. Developmental Psychology, 25, 729. https://doi.org/10.1037/0012-1649.25.5.729

Boyatzis, R. (2006). Intentional Change. Journal of Organizational Excellence, 25, 49-60. https://doi.org/10.1002/joe.20100

Creswell, J. W. (2011). Educational Research: Planning, Conducting, and Evaluating Quantative and Qualitative Research. New Jersey: Pearson Education International.

Day, D. V. (2000). Leadership Development: A Review in Context. The Leadership Quarterly, 11, 581-613. https://doi.org/10.1016/S1048-9843(00)00061-8

Day, D. V., \& Dragoni, L. (2015). Leadership Development: An Outcome-Oriented Review Based on Time and Levels of Analyses. Annual Review of Organizational Psychology and Organizational Behavior, 2, 133-156. https://doi.org/10.1146/annurev-orgpsych-032414-111328

DeRue, D. S., \& Myers, C. G. (2011). What Is Your Motivation for Learning? Cultural Differences and the Impact on Leader Development. In Annual Meeting of the Academy of Management, San Antonio, TX.

DeRue, D. S., \& Myers, C. G. (2014). Leadership Development: A Review and Agenda for Future Research (pp. 832-855). Oxford Handbook of Leadership and Organizations.

Edmonds, W. A., \& Kennedy, T. D. (2013). An Applied Reference Guide to Research Designs. Los Angeles: Sage.

Green, A., \& Erdem, M. (2016). Bridging the Gap between Academia and Industry in Hospitality: Using Real Life Case Studies. Developments in Business Simulation and Experiential Learning, 43, No. 1.

Hezlett, S. A. (2016). Enhancing Experience-Driven Leadership Development. Advances in Developing Human Resources, 18, 369-389. https://doi.org/10.1177/1523422316645887

Kellerman, B. (2012). The End of Leadership. New York, NY: Harper Business.

Kindstrom, D., \& Kowalkowsi, C. (2014). Service Innovation in Product-Centric Firms: A Multidimensional Business Model Perspective. Journal of Business and Industrial Marketing, 29, 96-111. https://doi.org/10.1108/JBIM-08-2013-0165

Kitterlin-Lynch, M., Williams, J., \& Zheng, T. (2015). Winning the Job Placement Competition: Industry's Message and Academia's Response. Journal of Hospitality \& Tourism Education, 27, 129-134. https://doi.org/10.1080/10963758.2015.1064318

Kolb, A. Y., \& Kolb, D. A. (2005). Learning Styles and Learning Spaces: Enhancing Experiential Learning in Higher Education. Academy of Management Learning \& Education, 4, 193-212. https://doi.org/10.5465/amle.2005.17268566

Kolb, D. (1984). Experiential Learning as the Science of Learning and Development.

Kuh, G. D., O’Donnell, K., \& Reed, S. (2013). Ensuring Quality and Taking High-Impact 
Practices to Scale. Washington DC: Association of American Colleges and Universities.

Lin, P. M., Kim, Y., Qiu, H., \& Ren, L. (2017). Experiential Learning in Hospitality Education through a Service-Learning Project. Journal of Hospitality \& Tourism Education, 29, 71-81. https://doi.org/10.1080/10963758.2017.1297716

Lives, G. J. G. (2014). The 2014 Gallup-Purdue Index Report. A Study of More Than, 30.

Lord, R. G., \& Hall, R. J. (2005). Identity, Deep Structure and the Development of Leadership Skill. The Leadership Quarterly, 16, 591-615. https://doi.org/10.1016/j.leaqua.2005.06.003

McCauley, C. D., DeRue, D. S., Yost, P. R., \& Taylor, S. (2014). Experience-Driven Leader Development: Models, Tools, Best Practices, and Advice for On-the-Job Development. John Wiley \& Sons.

Nikolova, N., \& Andersen, L. (2017). Creating Shared Value through Service-Learning in Management Education. Journal of Management Education, 41, 750-780. https://doi.org/10.1177/1052562917715883

Northouse, P. (2016). Leadership: Theory and Practice. Thousand Oaks, CA: Sage Publications.

Petrie, N. (2014). Vertical Leadership Development-Part 1 Developing Leaders for a Complex World. Colorado Springs, CO: Center for Creative Leadership.

Pine, B. J., \& Gilmore, J. H. (2011). The Experience Economy. Brighton, MA: Harvard Business Press.

Pine, B. J., \& Gilmore, J. H. (2014).A Leader's Guide to Innovation in the Experience Economy. Strategy \& Leadership, 42, 24-29. https://doi.org/10.1108/SL-09-2013-0073

Reichard, R. J., \& Johnson, S. K. (2011). Leader Self-Development as Organizational Strategy. The Leadership Quarterly, 22, 33-42. https://doi.org/10.1016/j.leaqua.2010.12.005

Ruhanen, L. (2006). Bridging the Divide between Theory and Practice: Experiential Learning Approaches for Tourism and Hospitality Management Education. Journal of Teaching in Travel \& Tourism, 5, 33-51. https://doi.org/10.1300/J172v05n04_03

Saldaña, J. (2015). The Coding Manual for Qualitative Researchers. Newcastle upon Tyne: Sage.

Schneider, C. G. (2015). The Leap Challenge: Transforming for Students, Essential for Liberal Education. Liberal Education, 101, 1-2.

Stansbie, P., Nash, R., \& Chang, S. (2016). Linking Internships and Classroom Learning: A Case Study Examination of Hospitality and Tourism Management Students. Journal of Hospitality, Leisure, Sport \& Tourism Education, 19, 19-29. https://doi.org/10.1016/j.jhlste.2016.07.001

Taylor, S. N., \& Hood, J. N. (2011). It May Not Be What You Think: Gender Differences in Predicting Emotional and Social Competence. Human Relations, 64, 627-652. https://doi.org/10.1177/0018726710387950

Testa, M. R., \& Sipe, L. (2012). Service-Leadership Competencies for Hospitality and Tourism Management. International Journal of Hospitality Management, 31, 648-658. https://doi.org/10.1016/j.ijhm.2011.08.009

Toffler, A. (1970). Future Shock. New York, NY: Amereon Ltd. 